\title{
Mechanical Properties of Clay Based Cemented Paste Backfill for Coal Recovery from Deep Mines
}

\author{
Qiangqiang Cheng ${ }^{1,2}$, Yaben Guo ${ }^{2}$, Chaowei Dong ${ }^{2, *}$, Jianfei $\mathrm{Xu}^{2}$, Wanan Lai ${ }^{2}$ and Bin Du ${ }^{1}$ \\ 1 School of Architectural Construction, Jiangsu Vocational Institute of Architectural Technology, \\ Xuzhou 221116, China; chengqiang_205@163.com (Q.C.); dubin_china@163.com (B.D.) \\ 2 School of Mines, China University of Mining and Technology, Xuzhou 221116, China; \\ GuoYaben819@163.com (Y.G.); xujianfei@cumt.edu.com (J.X.); laiwanan@cumt.edu.cn (W.L.) \\ * Correspondence: dongchaowei@cumt.edu.cn
}

Citation: Cheng, Q.; Guo, Y.; Dong, C.; Xu, J.; Lai, W.; Du, B. Mechanical Properties of Clay Based Cemented Paste Backfill for Coal Recovery from Deep Mines. Energies 2021, 14, 5764. https://doi.org/10.3390/en14185764

Academic Editors: Jixiong Zhang,

Dan Ma, Hao Yan and

Nikolaos Koukouzas

Received: 16 July 2021

Accepted: 9 September 2021

Published: 13 September 2021

Publisher's Note: MDPI stays neutral with regard to jurisdictional claims in published maps and institutional affiliations.

Copyright: (C) 2021 by the authors. Licensee MDPI, Basel, Switzerland. This article is an open access article distributed under the terms and conditions of the Creative Commons Attribution (CC BY) license (https:/ / creativecommons.org/licenses/by/ $4.0 /)$.

\begin{abstract}
Fly ash cement is used to solidify marine clay to prepare marine-clay-based cemented paste backfill (MCCPB) to fill the underground goaf of mines, which not only utilizes solid waste such as fly ash and marine clay, but also controls surface subsidence and protects the environment. To simulate the complex underground mine water environment of the filling body, a dry-wet cycle aquatic environment test under different material ratios and curing ages was designed. The water absorption and unconfined compression strength (UCS) of MCCPB with curing ages of 7 and 28 days under the action of $0,1,3$, and 7 dry-wet cycles were investigated. The results indicate as the number of dry-wet cycles increases, the surface of MCCPB becomes significantly rougher, and the water content and the solid mass decrease accordingly. Different ratios and curing ages of MCCPB in dry-wet cycles of the UCS tend first to increase, then decrease. Meanwhile, the stress-strain curve of the specimen shows that the trend in the elastic modulus is consistent with that of UCS (first increasing, then decreasing), and that, the minimum UCS value of the specimen still meets the early strength requirements of cemented paste backfill in coal mine geothermal utilization. On the one hand, it proves the feasibility of fly ash cement-solidified marine clay for use as cemented paste backfill in coal mines; on the other hand, it also expands the available range of cemented paste backfill materials in coal mines.
\end{abstract}

Keywords: mining and backfilling; fly ash cement-treated marine clays; dry-wet cycling; UCS; elastic modulus

\section{Introduction}

Cemented filling mining technology involves mixing mine solid waste (fly ash, tailings, construction waste, etc.), additives and water to prepare high-concentration cemented slurry without dehydration and pump the slurry to the underground goaf of the mine through a filling pump area, establishing a system for filling the underground mining space of mines. This technique has been widely applied in the global mining industry [1,2]. China's current accumulated bulk solid waste stockpiles amount to 60 billion tons, and new stockpiles add nearly 3 billion tons to that total [3], of which fly ash solid waste accounts for a net increase of nearly 100 million tons per year. It is estimated that the output of fly ash will reach 925 million tons in 2024 [4]. In addition, much high-plasticity marine clay composed of fine sand and clay will be produced during the construction of coastal engineering works [5]. This is mainly present as silt and silty soil, which has low bearing capacity and poor shear resistance [6]. The efficiency of direct utilization of marine clay by traditional methods is relatively low. In the future, China's bulk solid waste will still face high intensity, insufficient utilization, and occupy a large amount of land, posing greater hidden dangers to the environment. In response to the challenge of comprehensive utilization of solid waste, scholars have conducted extensive research into the utilization of fly ash, showing that the properties of the cementing materials 
prepared by using solid waste fly ash such as workability, heat of hydration, mechanical properties, permeability, and durability were improved (Table 1). It can be seen that the early strength of fly ash-based cementing materials can reach $2.3 \mathrm{MPa}$ and be used to prepare cementing filling materials to fill mine goaf and reduce the risk of surface subsidence [7]. Use of these materials not only reduces the cost of solid waste storage, but also provides an environmentally friendly way to deal with solid waste, thus solving the problem of solid waste accumulation polluting the environment and causing ground subsidence in mining areas [8]. Therefore, the cemented filling technique not only alleviates high in-situ stress in deep mining, but also controls the surface subsidence, improving the safety and efficient production of underground operation, and makes harmless and safe and effective use of solid waste resources, which has become an important part of green mining technology $[9,10]$.

Table 1. Summary of the main benefits and drawbacks of fly ash-based cementing materials.

\begin{tabular}{|c|c|c|c|}
\hline References & Cementing Materials & Benefits & Drawbacks \\
\hline $\begin{array}{l}\text { Saofee Dueramae } \\
\text { et al. [11] } \\
\text { Vishal Behl et al. [12] }\end{array}$ & fly ash concrete & $\begin{array}{l}\text { - improved workability } \\
\text { - decreased water demand } \\
\text { - reduction in heat of hydration } \\
\text { - increase in ultimate strength } \\
\text { - reduction in permeability }\end{array}$ & $\begin{array}{l}\text { - had low early strength and slow } \\
\text { later strength development. } \\
\text { - fly ash beyond } 50 \% \text { replacement } \\
\text { ratio strength reduces gradually. } \\
\text { - fly ash at higher replacement levels } \\
\text { results in a decrease in the tensile } \\
\text { strength of the mortar }\end{array}$ \\
\hline $\begin{array}{c}\text { Qiang et al. [13] } \\
\text { Chamila Gunasekara } \\
\text { et al. [14] }\end{array}$ & $\begin{array}{l}\text { fly ash-based } \\
\text { geopolymer concrete }\end{array}$ & $\begin{array}{l}\text { - reduce the diffusion and } \\
\text { penetration of chloride ions. } \\
\text { - higher sulfate resistance. } \\
\text { - better mechanical properties in the } \\
\text { initial stage of curing. }\end{array}$ & $\begin{array}{l}\text { - deforms faster than OPCC when } \\
\text { their stress reaches } 80 \% \text { of the } \\
\text { respective maximum stress. } \\
\text { - significantly higher corrosion rates } \\
\text { than OPC concrete. }\end{array}$ \\
\hline $\begin{array}{l}\text { Tang et al. [15] } \\
\text { Huang et al. [16] }\end{array}$ & class F fly ash & $\begin{array}{l}\text { - has low permeability and high } \\
\text { durability. } \\
\text { - has better stability and self-healing } \\
\text { ability under the same sulfate attack } \\
\text { environment. } \\
\text { - has good carbonation resistance. }\end{array}$ & $\begin{array}{l}\text { - the compressive strength and } \\
\text { flexural strength show a downward } \\
\text { trend. } \\
\text { - increases the pore pressure, } \\
\text { causing microcracks to develop } \\
\text { rapidly. } \\
\text { - ductility of ordinary concrete is } \\
\text { better than fly-ash-based polymer } \\
\text { concrete. }\end{array}$ \\
\hline $\begin{array}{c}\text { Du et al. [7] } \\
\text { Jiang et al. [17] } \\
\text { Ibrahim Cavusoglu } \\
\text { et al. [18] }\end{array}$ & $\begin{array}{c}\text { cemented coal fly ash } \\
\text { backfill }\end{array}$ & $\begin{array}{l}\text { - controlling the movement of } \\
\text { overlying strata thereby effectively } \\
\text { reducing surface subsidence. } \\
\text { - improves cementing performance } \\
\text { and reduces filling material cost. } \\
\text { - reduce shear friction between } \\
\text { aggregates. } \\
\text { - compressive strength and elastic } \\
\text { modulus increase with hydration } \\
\text { time and increase. }\end{array}$ & $\begin{array}{l}\text { - with an increase in particle size, the } \\
\text { fly-ash slurry stacking angle and } \\
\text { filling rate are found to decrease. } \\
\text { - poor fly ash was discarded, } \\
\text { occupied land, and polluted the } \\
\text { environment. } \\
\text { - low early strength, large } \\
\text { deformation, and severe bleeding. }\end{array}$ \\
\hline
\end{tabular}

Aiming at the special environment of high ground temperatures in deep mining, Liu et al. [19] established a conceptual model of functional filling materials that considers the expansion capabilities of cold loading, heat storage, energy storage, and seepage prevention in the deep mining environment. Zhang et al. [20] found that backfill goaf with the slurry containing ice granule can effectively alleviate the problems of high ground 
temperature while supporting stope in deep wells. Chen et al. [21] proposed a deep well adsorption cooling system based on thermal storage packing to tackle the problem of high ground temperature in deep wells. The research results show that this cooling system improves the downhole working face environment and exhibits the advantages of low energy consumption. It can be applied to high-temperature mines that use filling methods to control ground pressure. Zhang et al. [22] used tailings-cemented filling material as the research object, and evaluated the thermal conductivity, specific heat capacity, and compressive strength of the filling body under different filling material ratios. The results indicate that the larger the slurry concentration or cement-tailing ratio, the better the thermal conductivity, specific heat capacity, density, and compressive strength. GhoreishiMadiseh et al. [23] filled the goaf with cemented filling materials prepared by mixing tailings, cement, and water. The closed-loop pipe network was arranged inside the filling body, and the heat exchange between the filling body and the surrounding rock of the stope was conducted to realize the purpose of heat storage and energy storage. Wu et al. [24] investigated the heat generated by hydration of cemented filling materials prepared by coal gangue, binder, and water, as well as the heat transfer relationship between cemented materials and the surrounding environment. Furthermore, they established a numerical model to predict the temperature change in the hydration of cemented filling materials. The experimental results verified the correctness of the model. To date, researchers have extensively explored the heat transfer of cemented filling materials prepared by mixing tailings, coal gangue, fly ash, and additives to the surrounding rock of the mine stope. This proves that fly ash can be used as raw material to prepare cemented paste backfill for underground geothermal recovery in coal mines.

The use of marine clay is usually preceded by its being chemically stabilized with cement due to the poor engineering properties of marine clay [25,26]. Wang et al. [27] studied the compression and strength characteristics of marine beach soil solidified with magnesium oxide. Long-term changes in the mechanical properties of cement, fly ash, and lime were also measured; Chen et al. [28] used cement curing agent and lime curing agent to reinforce dredger fill to good effect; Chan et al. [29] conducted an exploratory study of the solidification of dredged marine clay from steel-making waste slag, and found that the cementing properties of slag strengthened the clay structure; Cheng et al. [30] assessed the stress-dependent behavior of fly ash cement (FAC)-mixed marine clay through isotropic consolidation drainage (CID) triaxial tests; Yao et al. [31] studied the effects of shear strain, mixing ratio, curing time, effective confining pressure, and stress on the shear stiffness of cement-treated clay, and proposed a framework for describing degradation of the modulus of cement-treated soft clay. The mechanical properties and structural stability of marine clay can be improved by using fly ash and cement to solidify marine clay. However, due to the complexity of the environment in the goaf of deep mines, it is necessary to study the mechanical properties of fly ash cement-solidified marine clay as marine clay-based cemented paste backfill for geothermal utilization of coal mines.

Fly ash cement-solidified marine clay filling for mine gobs is an effective way in which to utilize solid waste such as fly ash and marine clay. In the present research, marine clay and fly ash and other solid waste materials collected in Singapore were mixed to prepare standard specimens with different mix proportions and placed in a dry-wet cyclic aquatic environment for testing. The water content, mass loss, and uniaxial compressive strength (UCS) after 0, 1, 3, and 7 dry-wet cycles were measured after 7 and 28-day curing periods to assess the resistance of MCCPB made of marine clay solidified by fly ash cement to dry-wet cycling, and to assess the feasibility of MCCPB as cemented paste backfill for geothermal utilization in coal mines from the perspective of its mechanical properties. It not only expands the available range of cemented paste backfill materials suitable for use in coal mines, but also controls surface subsidence and protects the environment. 


\section{Materials and Experimental Methodology}

\subsection{Materials}

The materials used in this study include Singapore upper marine clay and fly ash cement CEM II/B-V (FAC, BS EN 197-1-2000). Figure 1 presents the physical and microscopic structure of fly ash cement CEM II/B-V. As shown in Figure 1, fly ash cement is dark grey fine powder and fly ash particles with coarse and lax structure is mostly anomalistic vitreous body with lots of cement fine particles wrapped on the surface. The marine clay was taken from a construction project in South Beach, Singapore. The site was excavated to a depth of approximately $10 \mathrm{~m}$. The main physical characteristics of the marine clay are listed in Table $2[32,33]$. The liquid limit and plastic limit of marine clay are $73 \%$ and $32 \%$, respectively, which indicates that the plasticity index is $41 \%$. The constituents of marine clay are approximately $25.2 \%$ clay, $66.08 \%$ silt, and $8.72 \%$ sand. The fly ash cement consists of $34.5 \%$ power-plant-coal fly ash and $65.5 \%$ Portland cement by weight. Table 3 summarizes the chemical composition of FAC by weight.

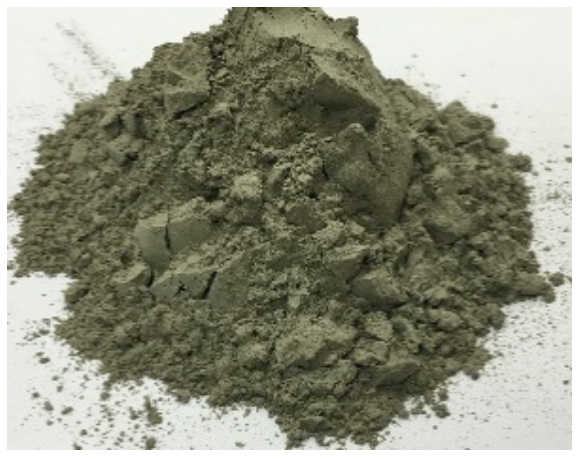

(a)

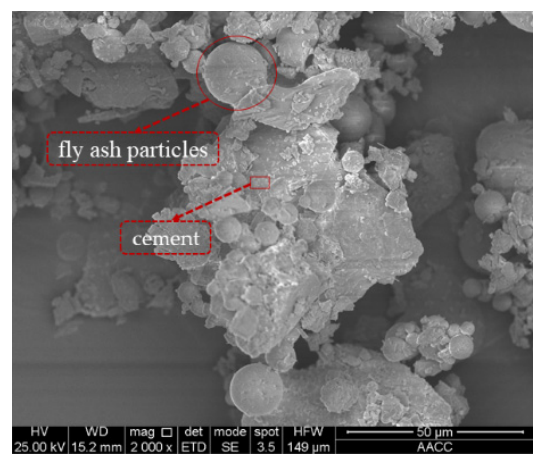

(b)

Figure 1. Physical and microscopic structure of fly ash cement. (a) Fly ash cement; (b) SEM micrograph of fly ash cement. Reprint with permission [34]; Copyright 2018, China University of Mining and Technology.

Table 2. Physical properties of marine clay.

\begin{tabular}{cccccccc}
\hline Location & \multicolumn{3}{c}{ Atterberg Limit } & \multicolumn{3}{c}{ Particle Size } & Remarks \\
\hline & LL & PL & PI & Clay & Silt & Sand & \\
Pulau Tekong & 88 & 38 & 50 & 20 & 72 & 8 & Xiao et al. [32] \\
Bugis & 74 & 31 & 43 & 33.24 & 55.50 & 11.26 & Xiao et al. [33] \\
South Beach & 73 & 32 & 41 & 25.2 & 66.08 & 8.72 & This study \\
\hline
\end{tabular}

Table 3. Chemical composition of FAC.

\begin{tabular}{cccccccccc}
\hline Chemical Composition & $\mathrm{SiO}_{2}$ & $\mathrm{Al}_{2} \mathrm{O}_{3}$ & $\mathrm{Fe}_{2} \mathrm{O}_{3}$ & $\mathrm{MgO}$ & $\mathrm{SO}_{3}$ & $\mathrm{~K}_{2} \mathrm{O}$ & $\mathrm{Na}_{2} \mathrm{O}$ & $\mathrm{Mn}_{2} \mathrm{O}_{3}$ & $\mathrm{CaO}$ \\
\hline CEM II/B-V (\%) & $50-55$ & $25-30$ & $4-7$ & $1-2$ & NA & $0-1$ & $1-2$ & NA & $4-7$ \\
\hline
\end{tabular}

\subsection{Specimen Preparation}

The mix ratio of fly ash cement-stabilized marine clay studied is 2:0.655:0.345:3, 1:0.655:0.345:2 and the curing times are 7 and 28 days. The mix ratio, for example 2:0.655:0.345:3, is expressed in terms of the ratio of dry marine clay $(\mathrm{M})$ :dry ordinary portland cement solid (C):dry fly ash solid (F):water (W) by weight [33]. The compressive strength of mix ratio 5:0.655:0.355:6 was demonstrated to be very low $[35,36]$. The mix ratio 2:0.655:0.345:3 and 1:0.655:0.345:2 was used in several cement clay stabilization projects, such as deep mixing and jet-grouting studies, and projects including soft, fine-grained soils $[37,38]$.

The main procedure of sample preparation is the same with that used by Cheng et al. [30]. The first step was to remove its small rocks, pebbles, seashells, etc. 
after soaking in water for several days and passing the material through a 0.3-mm sieve to ensure the homogeneity of the clay. Then the marine clay was mixed in a Hobart mixer for $10 \mathrm{~min}$ to $90 \%$ moisture content. The mass of fly ash cement and water required were then calculated according to the designing mix proportions. Both fly ash cement and water left according to the desired ratio 2:0.655:0.345:3, 1:0.655:0.345:2 were added and mixed for another $10 \mathrm{~min}$. The mixture was then placed in a cylindrical polyvinyl chloride spit-mold, which was vibrated on a vibrating table to expel the entrapped air. Later, the prepared mixture was placed into prepared molds in five layers using artificial vibration: the specimens measured $50 \mathrm{~mm}$ in diameter by $100 \mathrm{~mm}$ in height. The last step was to cure the specimen under distilled water without loading (Figure 2). It should be noted that all specimens should be prepared within half an hour. Table 4 lists the basic parameters of specimen tested in this study.
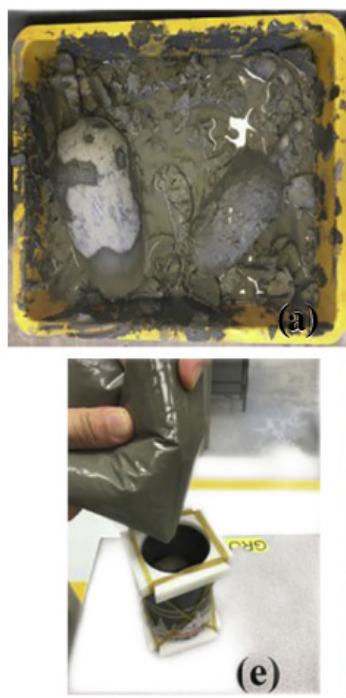

(e)

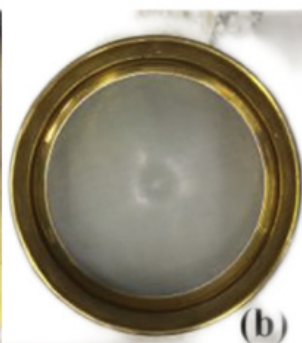

(b)

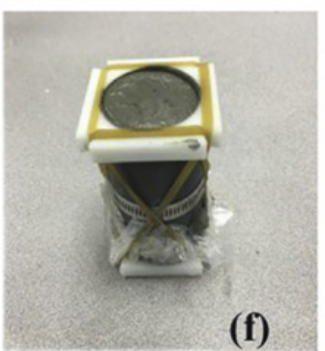

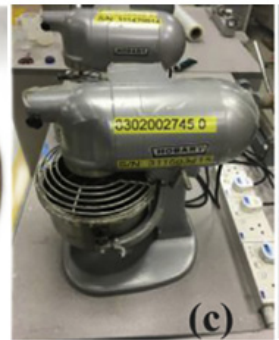
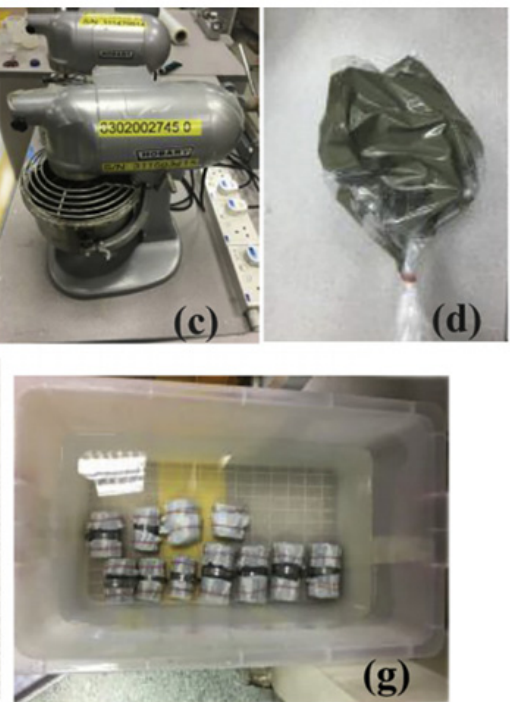

Figure 2. Specimen preparation procedure. (a) MCCPB—admixed clay; (b) Sieve; (c) Hobart mixer; (d,e) Admixture in plastic bag; (f) Molded sample; (g) Samples were cured in distilled water.

Table 4. Basic parameters of the test specimens.

\begin{tabular}{|c|c|c|c|c|c|c|c|c|c|c|}
\hline $\begin{array}{l}\text { Mix Ratio } \\
\text { M:C:F:W }\end{array}$ & $\begin{array}{l}\text { Curing } \\
\text { Time } \\
\text { (Days) }\end{array}$ & $\begin{array}{l}\text { Dry-Wet } \\
\text { Cycles }\end{array}$ & $\begin{array}{c}\text { Number } \\
\text { of Speci- } \\
\text { mens }\end{array}$ & $\begin{array}{c}\text { Sample } \\
\text { Diameter } \times \\
\text { Height } \\
(\mathbf{m m} \times \mathbf{m m})\end{array}$ & $\begin{array}{l}\text { Average } \\
\text { Sample } \\
\text { Mass in } \\
\text { the Air (g) }\end{array}$ & $\begin{array}{c}\text { Average } \\
\text { Sample } \\
\text { Mass in } \\
\text { the } \\
\text { Water (g) }\end{array}$ & $\begin{array}{l}\text { Density } \\
\left(\mathrm{g} / \mathrm{cm}^{3}\right)\end{array}$ & $\begin{array}{c}\text { Water } \\
\text { Content } \\
(\%)\end{array}$ & UCS (kPa) & $\begin{array}{c}\text { UCS } \\
\text { Standard } \\
\text { Deviation }\end{array}$ \\
\hline \multirow{8}{*}{ 2:0.655:0.345:3 } & \multirow{4}{*}{7} & 0 & 5 & $50.32 \times 100.26$ & 292.3 & 93.6 & 1.515 & 91.30 & 520.9 & 3.399 \\
\hline & & 1 & 5 & $49.56 \times 99.16$ & 280.1 & 92.4 & 1.513 & 90.72 & 553.6 & 2.395 \\
\hline & & 3 & 5 & $49.58 \times 98.72$ & 278.6 & 91.8 & 1.511 & 85.83 & 657.4 & 3.252 \\
\hline & & 7 & 5 & $50.78 \times 99.27$ & 281.9 & 92.6 & 1.494 & 85.62 & 455.8 & 4.584 \\
\hline & \multirow{4}{*}{28} & 0 & 5 & $50.34 \times 99.76$ & 290.0 & 93.4 & 1.509 & 91.76 & 739.6 & 4.176 \\
\hline & & 1 & 5 & $49.96 \times 98.81$ & 281.6 & 92.5 & 1.502 & 91.24 & 746.0 & 2.159 \\
\hline & & 3 & 5 & $49.65 \times 99.74$ & 280.7 & 92.2 & 1.502 & 88.67 & 810.5 & 4.014 \\
\hline & & 7 & 5 & $50.35 \times 99.91$ & 290.0 & 93.3 & 1.506 & 88.25 & 721.0 & 4.069 \\
\hline \multirow{8}{*}{ 1:0.655:0.345:2 } & \multirow{4}{*}{7} & 0 & 5 & $50.02 \times 99.96$ & 290.4 & 93.1 & 1.527 & 92.40 & 907.6 & 4.266 \\
\hline & & 1 & 5 & $50.22 \times 99.82$ & 287.9 & 93.1 & 1.505 & 92.53 & 1006.4 & 7.225 \\
\hline & & 3 & 5 & $50.29 \times 99.84$ & 289.0 & 93.1 & 1.506 & 91.77 & 1150.1 & 2.949 \\
\hline & & 7 & 5 & $50.35 \times 99.91$ & 291.6 & 93.5 & 1.514 & 91.68 & 780.2 & 3.291 \\
\hline & \multirow{4}{*}{28} & 0 & 5 & $50.45 \times 99.88$ & 291.8 & 93.7 & 1.524 & 86.52 & 1552.1 & 3.005 \\
\hline & & 1 & 5 & $50.52 \times 99.91$ & 293.8 & 93.6 & 1.516 & 86.04 & 1594.2 & 4.059 \\
\hline & & 3 & 5 & $49.96 \times 99.92$ & 289.3 & 93.1 & 1.526 & 85.94 & 1684.2 & 5.404 \\
\hline & & 7 & 5 & $50.41 \times 99.96$ & 292.5 & 93.4 & 1.513 & 86.00 & 1473.5 & 4.013 \\
\hline
\end{tabular}




\subsection{Cyclic Dry-Wet Environment}

The experiments of drying-wetting cycles on $\mathrm{MCCPB}$ were designed in accordance with the Standard for Test Methods of Long-term Performance and Durability of Ordinary Concrete (GB/T 50082-2009).

The cyclic drying-wetting test was conducted on MCCPB in deionized water under the following conditions: MCCPB was first soaked in deionized water for $24 \mathrm{~h}$, and then oven-dried for $24 \mathrm{~h}$, soaking for $24 \mathrm{~h}$ and then drying for $24 \mathrm{~h}$ constituted one cycle and experiments over $0,1,3$, and 7 drying-wetting cycles were conducted. The samples were dried at room temperature and then in air for $24 \mathrm{~h}$. The samples were soaked in deionized water for $24 \mathrm{~h}$. The mass and water content of the solidified marine clay were recorded after each drying and wetting cycle.

\subsection{Analytical Methods}

The water content of the MCCPB samples was determined in accordance with CENISO/TS 17892-1 [39] by blast drying oven (Instrument type: BGZ-140), which was capable of maintaining a uniform temperature of $105^{\circ} \mathrm{C} \pm 5^{\circ} \mathrm{C}$ throughout the drying chamber. The specific formula for calculating water content was introduced, that is,

$$
w=\left(m_{w} / m_{d}\right) \times 100
$$

where, $w$ is the water content $(\%) ; m_{w}$ is the mass of water $(\mathrm{g}) ; m_{d}$ is the mass of dried test specimen $(\mathrm{g})$.

The bulk density for MCCPB samples was determined in accordance with CENISO/TS 17892-2 [39] by a balance (Instrument type: MS6002TS/02) and Vernier calipers (Instrument type: 530-312); the bulk density $\rho$ is given by Equation (2):

$$
\rho=\frac{\mathrm{m}}{V}\left(\text { in } \mathrm{Mg} / \mathrm{m}^{3}\right)
$$

where, $\mathrm{m}$ is the specimen mass $(\mathrm{g}) ; V$ is the volume of the specimen $\left(\mathrm{cm}^{3}\right)$

The UCS values were tested according to CEN-ISO/TS 17892-7 [39] by an electrohydraulic servo universal test machine (Instrument type: WAW-1000D). The displacement rate was $0.05 \mathrm{~mm} / \mathrm{min}$, as applied to MCCPB specimens after $0,1,3$, and 7 cycles, respectively.

\section{Results and Discussion}

\subsection{Water Absorption and Dehydration of $М С C P B$}

Figure 3 presents photographs of fly ash cement-treated marine clay under different conditions of dry-wet cycling taking a mix ratio 2:0.655:0.345:3 and curing time of 28 days as an example. There is no obvious change in the surface of fly ash cement-treated marine clay after one dry-wet cycle; however, after three cycles, the surface of the specimen began to become rough. After 7 cycles, there was slight peeling and tiny voids on the surface, and the edge of the sample was partially peeled off. There was no significant crack and surface peeling during the process of dry-wet cycling. At the beginning of each wetting stage, and upon ending of each drying stage, powder could be seen falling from fly ash cement-treated marine clay specimens in deionized water. 


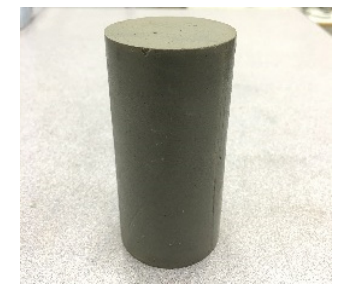

0 cycle

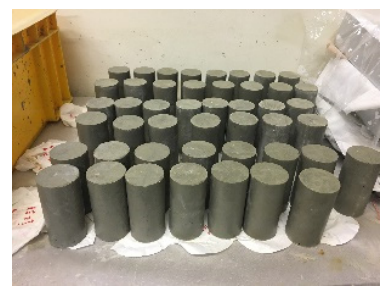

1 cycle

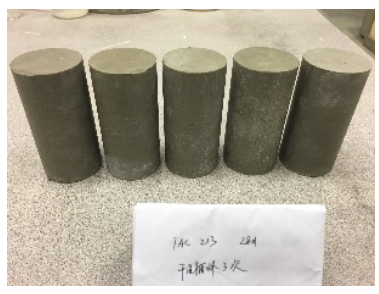

3 cycles

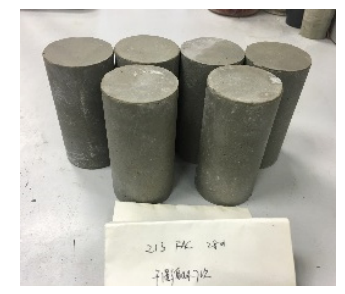

7 cycles

Figure 3. The changes of the MCCPB surface.

As shown in Figure 4, the water content decreases as the number of dry and wet cycles increases. The water content at a mix ratio 2:0.655:0.345:3 reduces faster than that at 1:0.655:0.345:2, especially after three dry and wet cycles. After three cycles, the water content changes are insignificant. This is mainly because fly ash in fly ash cement participates in the hydration reaction, mainly concentrated in the longer curing period. The fly ash is still involved in hydration reaction with the mix ratio 1:0.655:0.345:2 throughout dry-wet cycling, matching the findings in [40].

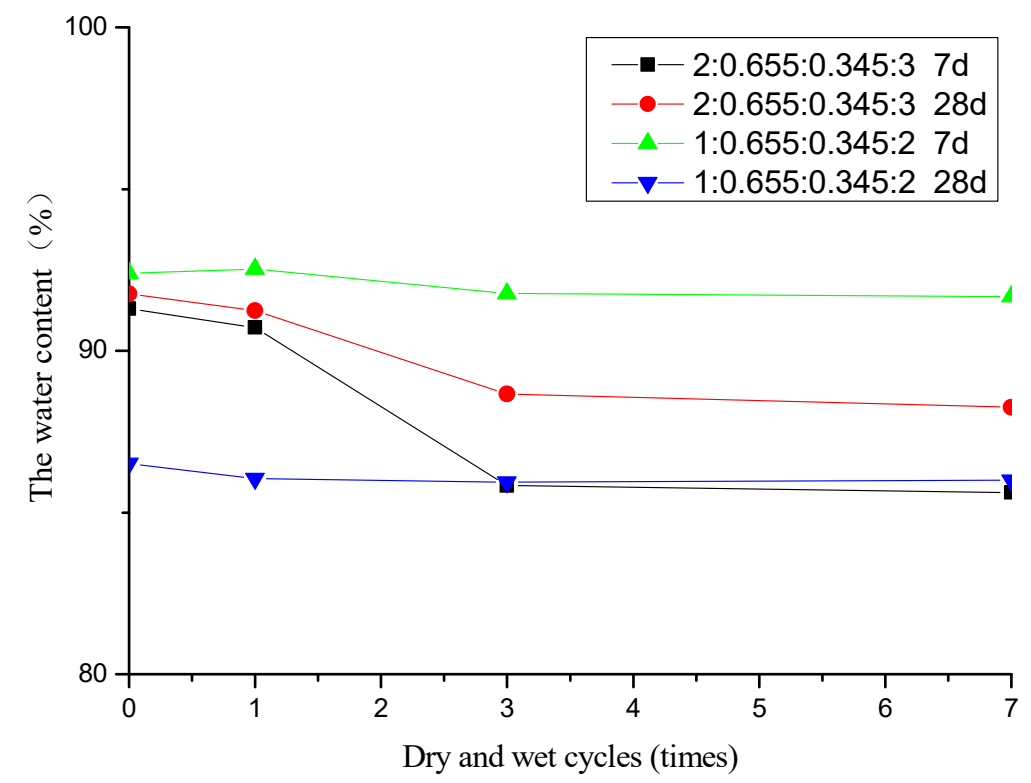

Figure 4. The water content of different mix ratios varies with dry-wet cycling.

Figure 5 presents the variation of the specimen quality: the quality of specimens with different mix ratios decreases with increasing dry-wet cycling. The curve for mix ratio 2:0.655:0.345:3 was relatively flat, and the quality after seven cycles was $2.3 \%$ (curing time $7 \mathrm{~d}$ ) and $3.2 \%$ (curing time $28 \mathrm{~d}$ ) of the original mass. The quality degradation after seven cycles is more significant than that after three cycles or one cycle. Independent of mix ratio, the experimental results show that the percentage of quality declines after 7 dry and wet cycles is similar, reaching 5.2\% with mix ratio 1:0.655:0.345:2 and a curing time of $28 \mathrm{~d}$. In the fly ash cement-treated marine clay, the change in quality over seven cycles is insignificant compared with other studies [41]. 


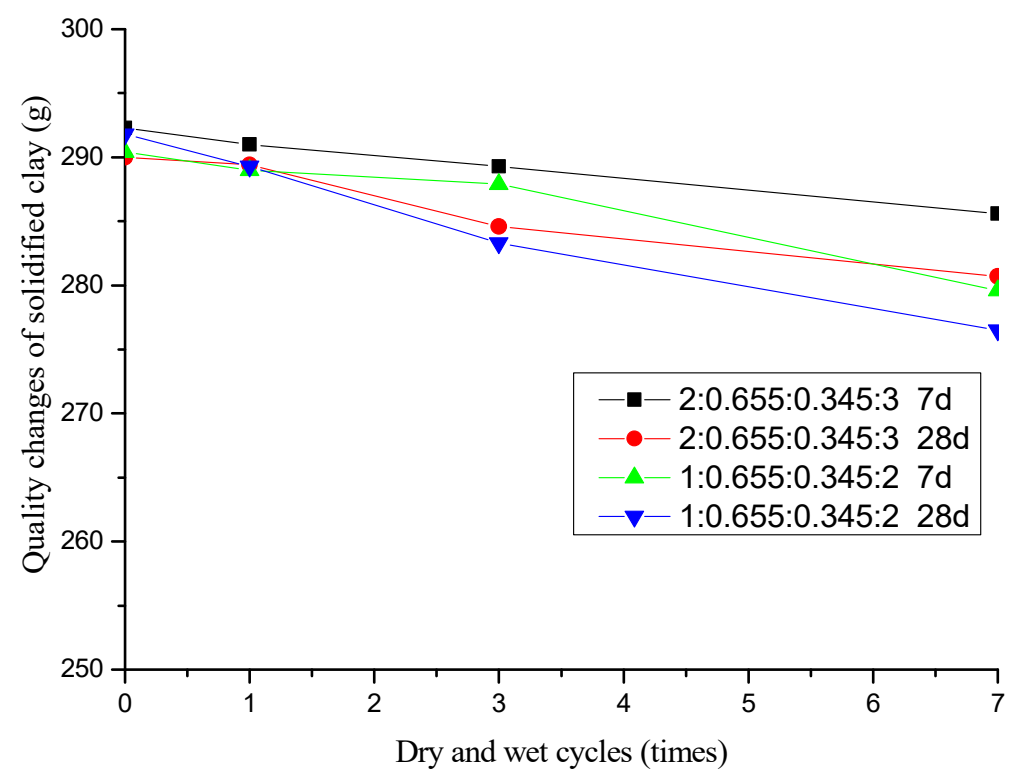

Figure 5. The quality of different mix ratios varies with dry-wet cycles.

\subsection{Effect of Dry-Wet Cycles on Compressive Strength of MCCPB}

In the process of coal mine filling, the filling material needs a certain bearing capacity of its own to ensure that the supporting direct roof does not deform at the initial stage of the filling operation, so as to avoid the subsidence or collapse of the basic roof strata due to large-scale deformation of the direct roof, which ultimately leads to surface settlement (Figure 6). Therefore, in the initial stage, the load acting on the filling material is the dead weight load of the immediate roof rock layer, which is equivalent to that of the early strength of the filling material to bear the dead weight of the immediate roof rock layer. The early strength required here is UCS after 7 days of maintenance of the filling material. For early strength, the required strength is determined thus [42]:

$$
\sigma_{\mathrm{s}}=\alpha \times \beta \times \rho_{r} \times g \times h
$$

where, $\sigma_{\mathrm{S}}$ represents early strength; $\alpha$ is the ratio between the UCS of laboratory sample test and field test (with a value usually between 1.1 and 1.3); $\beta$ is the safety coefficient (with a value usually between 1.3 and 2.0); $\rho_{r}$ is the density of the immediate roof $\left(1900-2700 \mathrm{~kg} / \mathrm{m}^{3}\right) ; g$ denotes the acceleration due to gravity $(10 \mathrm{~N} / \mathrm{kg}) ; h$ is the thickness of the direct roof (1.2 4.6 m); based on the empirical conditions, the value of each parameter is set to its maximum case and the required minimum early strength is $323 \mathrm{kPa}$.

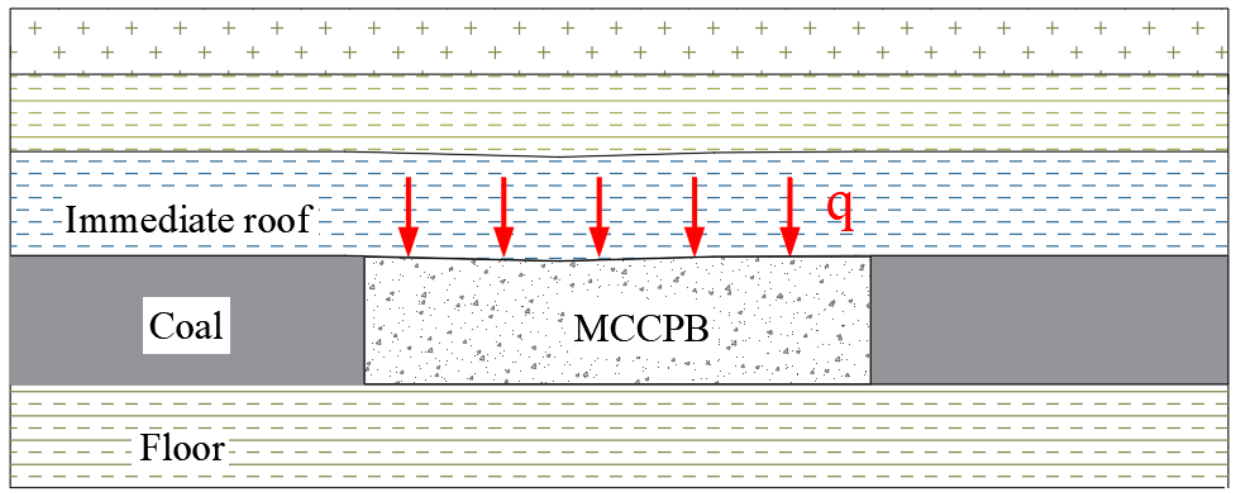

Figure 6. Relationship between overlying strata and backfill. 
According to the UCS test results, the peak strengths with different mix ratios and curing times after $0,1,3$, and 7 cycles were sorted (Figures 7 and 8 ). The rate of change in strength is defined as the ratio of strength of specimen under dry and wet cycling condition and under standard maintenance conditions.

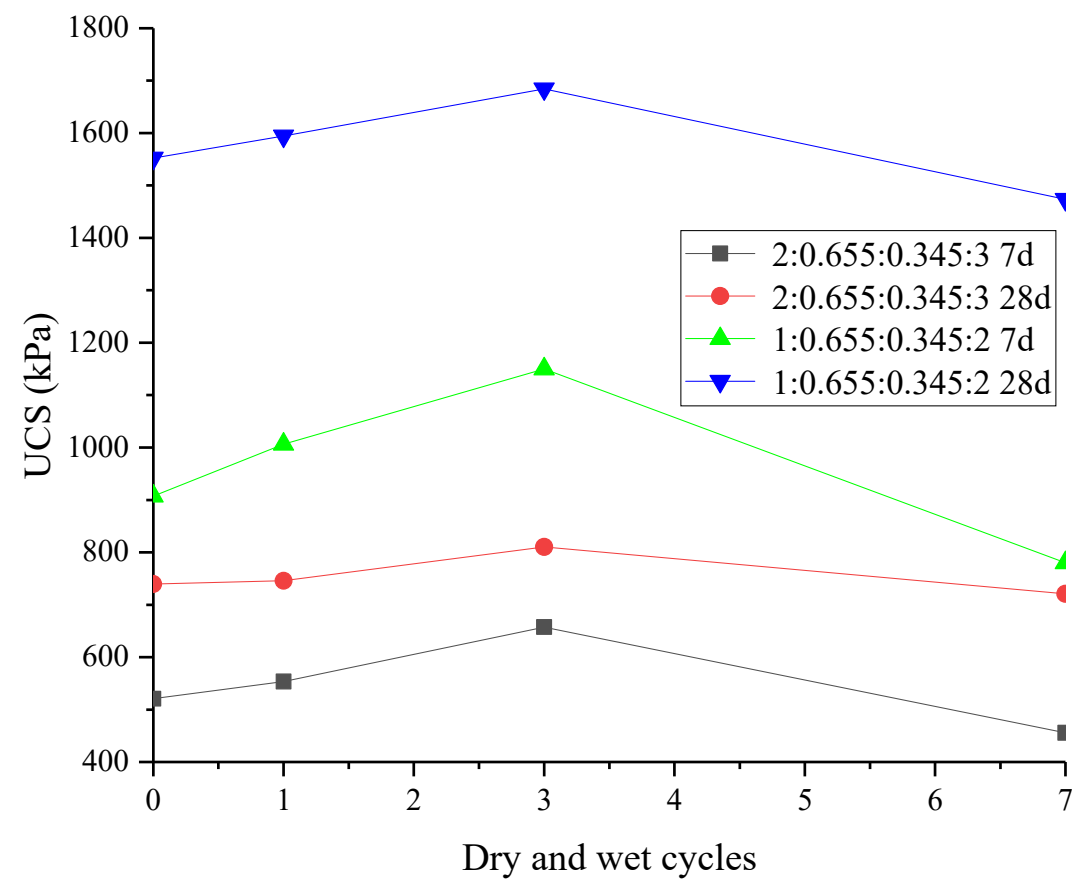

Figure 7. The UCS changes of MCCPB with dry-wet cycles.

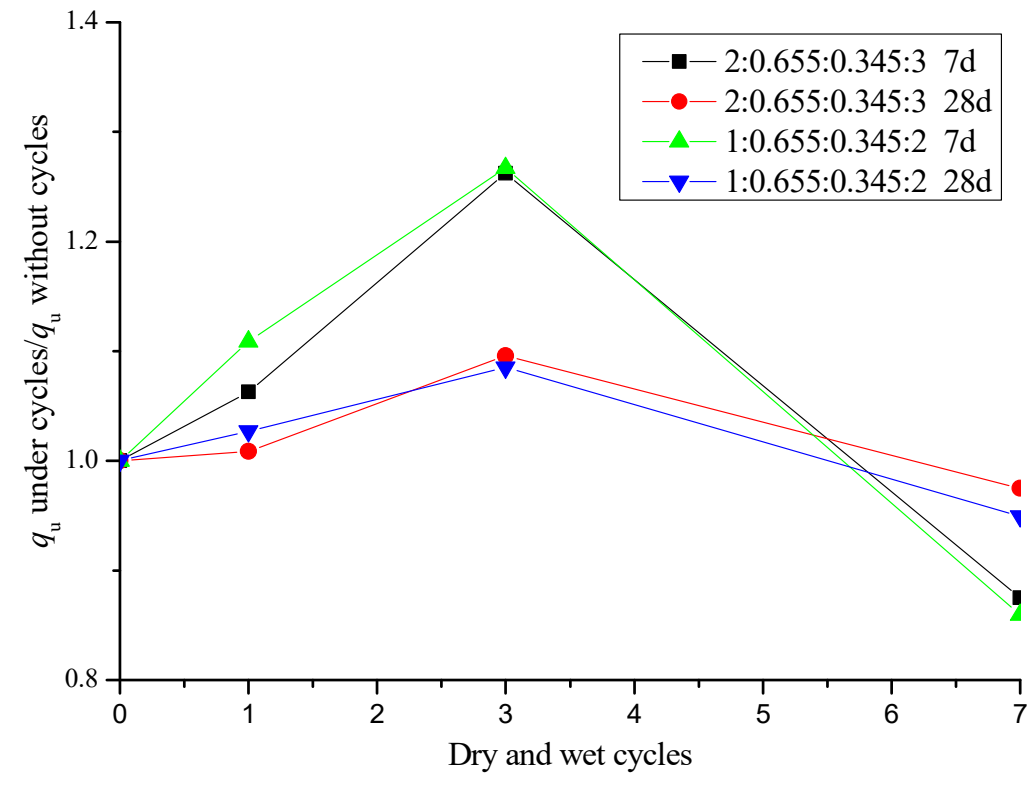

Figure 8. The change rate of UCS with dry-wet cycles.

Figure 7 shows the unconfined compressive strength of the specimen with different mix ratios under different curing time conditions: after one or three dry and wet cycles it showed an increasing trend; however, it then decreased after 7 cycles. The peak UCS of the specimen with the ratio of 2:0.65:0.345:3 was the lowest when cured for $7 \mathrm{~d}$. Without the erosion caused by drying-wetting cycles, the UCS reached $520.9 \mathrm{kPa}$. After 7 dry-wet cycles, the peak UCS decreased to $455.8 \mathrm{kPa}$. The early strength remained greater than $323 \mathrm{kPa}$, meeting the requirements of mine filling materials for early strength. The peak 
UCS under other erosion conditions meet the requirements of early strength. Therefore, fly ash cement solidified marine clay can be prepared as cementing filling material to backfill goaf of mine.

Figure 8 shows that the UCS after one cycle, three cycles, and seven cycles is $110 \%, 130 \%$, $90 \%$ of the original value after curing for 7 days when using a mix ratio of 2:0.655:0.345:3 and 1:0.655:0.345:2. For the specimens cured for $28 \mathrm{~d}$ under different mix ratios, the UCS after 1 cycle, 3 cycles, 7 cycles is 103\%, 110\%, 95\% of the original value. The unconfined compressive strength changes after a curing time of 28 days, which is significantly higher than that after 7 days under the same mix ratio and the same number of cycles. In specimens cured for 7 days, the peak strength is still approximately $90 \%$ of original value, which indicates that the fly ash cement-treated marine clay has better water stability.

\subsection{Effect of Dry-Wet Cycles on $E_{50}$ and Stress-Strain Curves}

In this research, the elasticity modulus was used to measure the resistance to elastic deformation of MCCPB; that is, the secant modulus $\left(E_{50}\right)$ is given by the slope of the line between the origin of the stress-strain curve and the point corresponding to $50 \%$ of the failure stress (Figure 9).

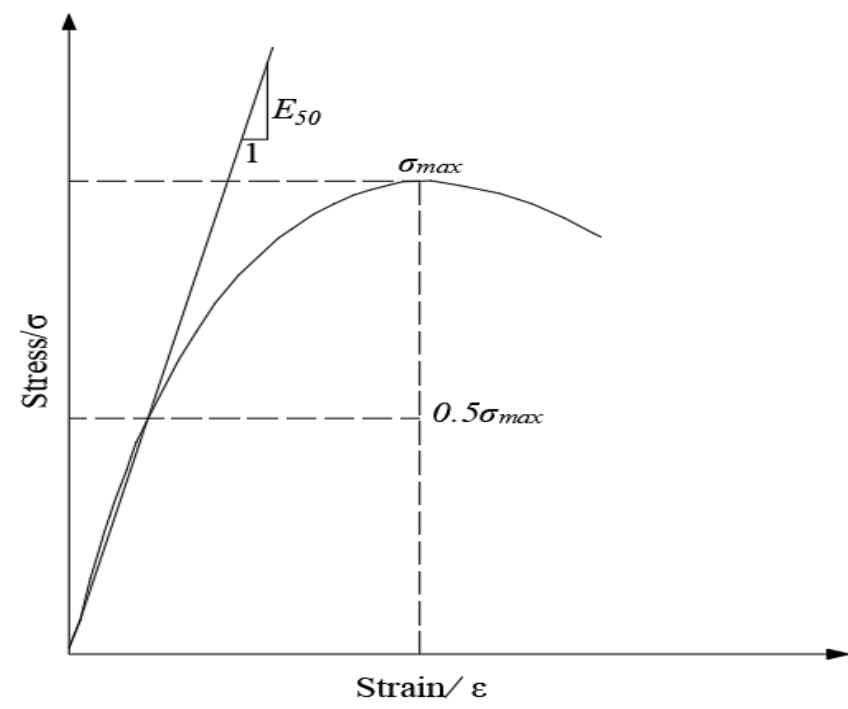

Figure 9. Schematic diagram of determination of secant modulus $\left(E_{50}\right)$.

To study the effects of dry and wet cycles on the deformation properties of fly ash cement-treated marine clay, the secant modulus $E_{50}$ corresponding to the $50 \%$ of the peak point, as shown in Figure 10, was used. $E_{50}$ has an increasing, then decreasing trend with increasing dry-wet cycling. $E_{50}$ can reach $150 \%$ of original standard curing specimen value after three cycles. Even after seven cycles, the $E_{50}$ value is largely unchanged compared with the original value.

Stress-strain curves are shown in Figure 11. The stress-strain curve of fly ash cementsolidified marine clay changed at the peak after different numbers of dry-wet cycles, but the strain did not change significantly. The maximum strength loss is only $10 \%$ of the initial value after 7 dry-wet cycles after a curing time of 7 days, which indicates that the strength and deformation of MCCPB are less affected by dry-wet cycling. When broken, the corresponding axial strain decreases as the number of dry and wet cycles increased after a curing time of 7 days, whereas specimens cured for 28 days presented the opposite trend. The peak residual strength of fly ash cement-solidified marine clay increases with increasing dry-wet cycling for both mix ratios and both curing times. 


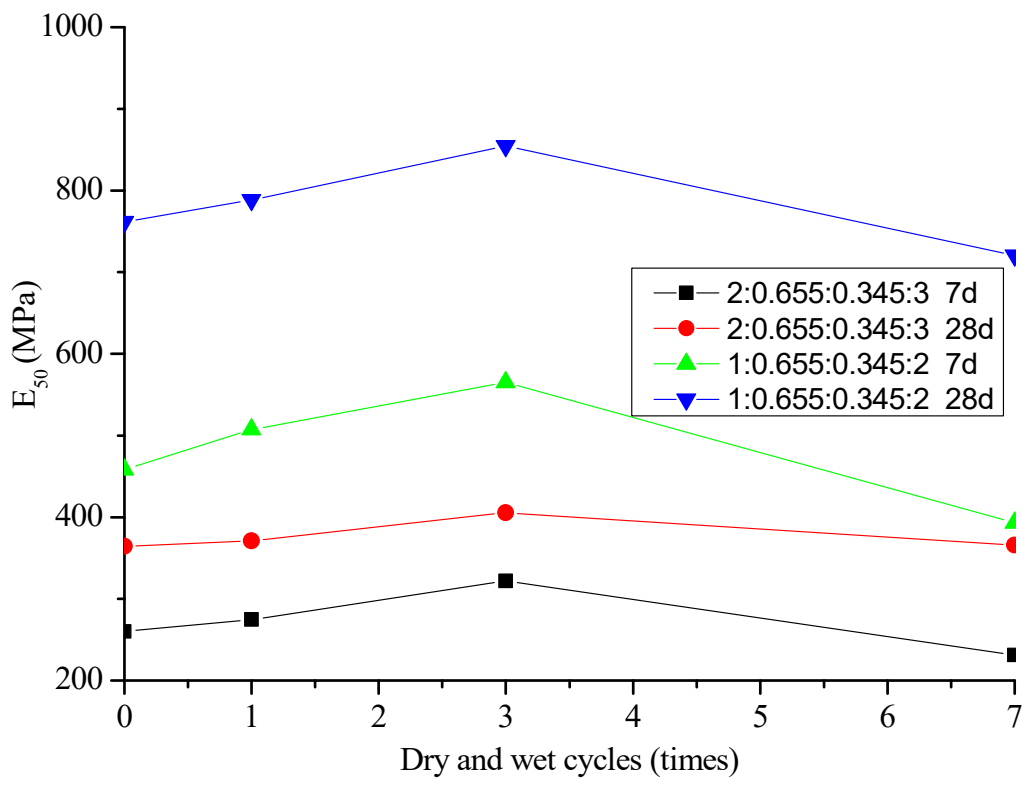

Figure 10. Changes in $E_{50}$ of $\mathrm{MCCPB}$ with dry-wet cycles.

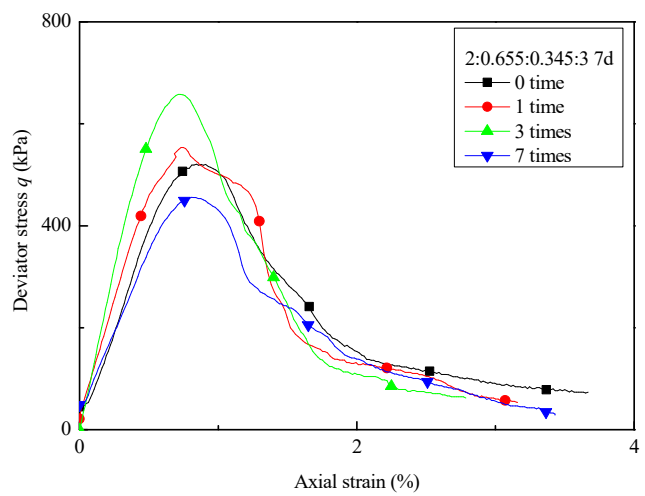

(a)

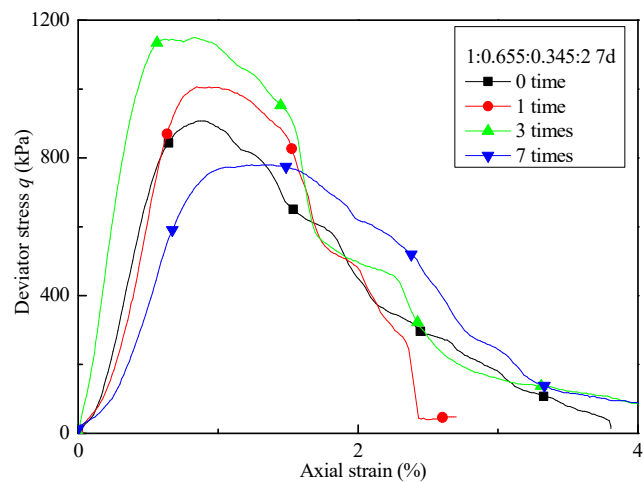

(c)

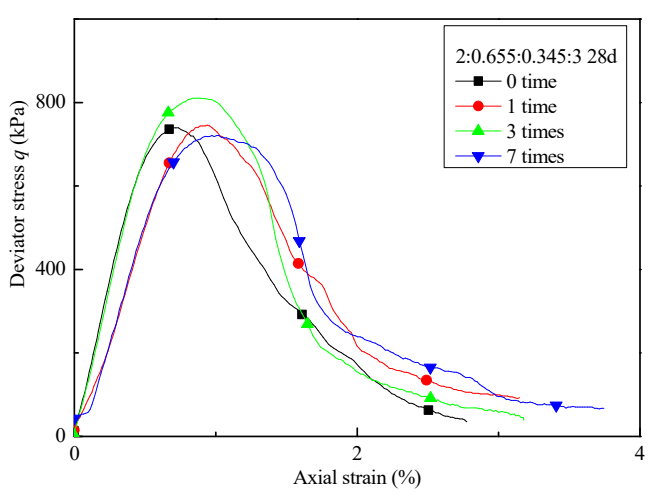

(b)

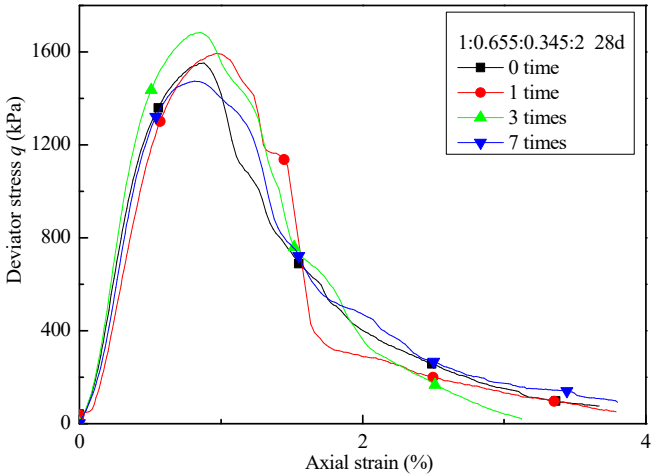

(d)

Figure 11. Stress-strain curves of MCCPB with different dry-wet cycles. (a) 2:0.655:0.345:3 curing time 7 d. (b) 2:0.655:0.345:3 curing time $28 \mathrm{~d}$. (c) 1:0.655:0.345:2 curing time $7 \mathrm{~d}$. (d) 1:0.655:0.345:2 curing time $28 \mathrm{~d}$.

Figure 12 presents the tested photos of different cycles with a mix ratio of 2:0.655:0.345:3, after a curing time of $28 \mathrm{~d}$. The number of potential weak faces in the fly ash cementsolidified marine clay increases upon wet-dry cycling. 


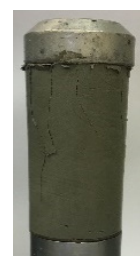

0 cycle

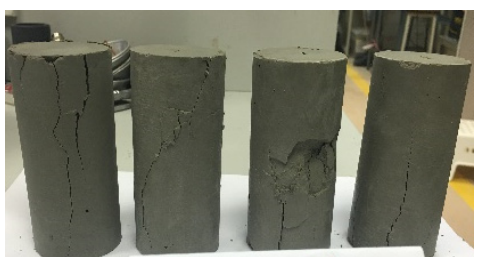

1 cycle

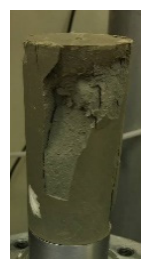

3 cycles

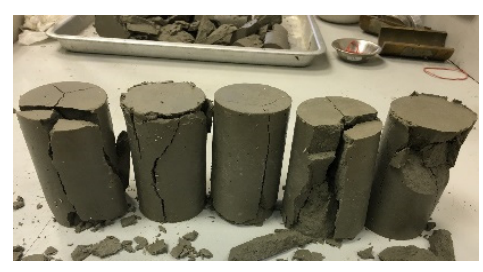

7 cycles

Figure 12. The UCS test photos of MCCPB with different dry-wet cycles (2:0.655:0.345:3 28 d).

\section{Conclusions}

In this study, two specimens were prepared using the mass ratios of marine clay, fly ash, cement and water, and the water content and mechanical properties were studied under different maintenance conditions and different numbers of dry-wet cycles. The following conclusions were drawn:

1. After dry-wet cycling, the water content of the $\mathrm{MCCPB} \mathrm{decreased} \mathrm{slightly,} \mathrm{and} \mathrm{the}$ tendency of mix ratio 2:0.655:0.345:3 decreased greater than 1:0.655:0.345:2 under the same cycling conditions. The quality of specimens with different mix ratios decreased with the increasing number of dry-wet cycles (with the maximum reaching $5.2 \%$ for a mix ratio of 1:0.655:0.345:2 and a curing time of $28 \mathrm{~d}$ ). There was no significant cracking and surface peeling during the process of dry-wet cycling, regardless of mix ratio or curing time.

2. The UCS of the specimen with different mix ratio and different curing time conditions first increased, then decreased with increasing dry-wet cycling. After a curing time of $7 \mathrm{~d}$, the minimum peak strength was still approximately $90 \%$ of the original value, and the minimum UCS value of the specimen still met the early strength requirements of cemented paste backfill in a coal mine, which indicates that it is feasible to use fly ash cement to solidify marine clay to prepare mine cemented filling material.

3. After seven cycles, the $E_{50}$ value was similar to its original value. The strain did not change significantly. The peak residual strength of MCCPB increased with increasing dry-wet cycling for both mix ratios and both curing times.

Based on the above characteristics, fly ash cement-solidified marine clay can be used as coal mine cemented paste backfill, which not only effectively utilizes solid waste such as fly ash and marine clay and protects the environment, but also expands the available range of cemented paste backfill materials for use in coal mines.

Author Contributions: All of the authors contributed extensively to the present paper. Q.C. and C.D. conceived and provided theoretical and methodological guidance in the research. Y.G. and Q.C. designed the experiments, processed and analyzed the data. C.D. and J.X. performed the experiments. W.L. and B.D. reviewed and revised the manuscript extensively. All authors have read and agreed to the published version of the manuscript.

Funding: This research was funded by the National Natural Science Foundation of China (52004105); Qing Lan Project and General Projects of Natural Science Fund Project of Colleges in Jiangsu Province (20KJB170024, 20KJA560002, 20KJB410002) as well as Xuzhou Science and Technology Project (KC20199, KC19012); the Postgraduate Research \& Practice Innovation Program of Jiangsu Province (KYCX21_2381).

Institutional Review Board Statement: Not applicable.

Informed Consent Statement: Not applicable.

Data Availability Statement: Not applicable.

Acknowledgments: The author gratefully acknowledge the support provided by National University of Singapore; the Jiangsu Overseas Research \& Training Program for University Prominent Young \& Middle-aged Teachers and Presidents; the Postgraduate Research \& Practice Innovation Program of Jiangsu Province. 
Conflicts of Interest: The authors declare no conflict of interest.

\section{References}

1. Cui, L.; Mamadou, F. An evolutive elasto-plastic model for cemented paste backfill. Comput. Geotech. 2016, 71, 19-29. [CrossRef]

2. Zhou, N.; Zhang, J.; Ouyang, S.; Deng, X.; Dong, C.; Du, E. Feasibility study and performance optimization of sand-based cemented paste backfill materials. J. Clean. Prod. 2020, 259, 120798. [CrossRef]

3. National Development and Reform Commission, PRC. Guidance on Comprehensive Utilization of '14th Five-Year' Solid Waste; National Development and Reform Commission, PRC: Beijing, China, 2021.

4. Liu, H.F.; Zhang, J.X.; Zhou, N.; Shen, L.L.; Zhang, L.B.; Zhu, C.L.; Wang, L. Study of the leaching and olidification mechanism of heavy metals from gangue-based cemented paste backfilling materials. J. China Univ. Min. Technol. 2021, 50, 523-531.

5. Bak, S.J.W.; Mohd, Y.N.Z.; Saleh, S.; Ahmad, K.; Rahim, A.; Mat, S.K. The Effect of Polyurethane Mix Ratio on the Strength of Polyurethane Treated Marine Clay. Mater. Sci. Eng. 2021, 1144, 12079.

6. Hanis, A.N.H.; Syahirah, A.; Talib, A.A.N.; Najwa, I.N.I. Plasticity and Strength Behaviour of Marine Clay Stabilized with Waste Steel Dust for Soil Improvement Works. Key Eng. Mater. 2021, 6206, 91-99. [CrossRef]

7. Liu, W.; Guo, Z.; Wang, C.; Niu, S. Physico-mechanical and microstructure properties of cemented coal Gangue-Fly ash backfill: Effects of curing temperature. Constr. Build. Mater. 2021, 299, 124011. [CrossRef]

8. Erol, Y.; Tikou, B.; Mostafa, B. Effects of curing and stress conditions on hydromechanical, geotechnical and geochemical properties of cemented paste backfill. Eng. Geol. 2014, 168, 23-37.

9. Yin, S.H.; Shao, Y.J.; Wu, A.X.; Wang, H.J.; Liu, X.H.; Wang, Y. A systematic review of paste technology in metal mines for cleaner production in China. J. Clean. Prod. 2020, 247, 119590. [CrossRef]

10. Yan, H.; Zhang, J.X.; Li, B.Y.; Zhu, C.L. Crack propagation patterns and factors controlling complex crack network formation in coal bodies during tri-axial supercritical carbon dioxide fracturing. Fuel 2021, 286, 119381. [CrossRef]

11. Saofee, D.; Weerachart, T.; Chai, J. Strength and heat generation of concrete using carbide lime and fly ash as a new cementitious material without Portland cement. Adv. Powder. Technol. 2018, 29, 672-681.

12. Vishal, B.; Vinay, S.; Vijay, D.; Ajay, K. Characterization of physico-chemical and functional properties of fly ash concrete mix. Mater. Today Proc. 2021, 2214-7853. [CrossRef]

13. Fu, Q.; Xu, W.R.; Zhao, X.; Bu, M.X.; Yuan, Q.; Niu, D. The microstructure and durability of fly ash-based geopolymer concrete: A review. Ceram. Int. 2021, in press. [CrossRef]

14. Chamila, G.; David, L.; Shamir, B.; Sujeeva, S.L.W. Chloride induced corrosion in different fly ash based geopolymer concretes Constr. Build. Mater. 2019, 200, 502-513.

15. Tang, L.; Huang, Q.; Wang, Q.Y.; Zhang, H.E.; Shi, X.S. Research on corrosion resistance and relevant mechanism of geopolymer concrete and ordinary concrete in the same sulfate solution Mater. Mater. Rep. 2015, 29, 129-134.

16. Huang, Q.; Shuang, X.S.; Wang, Q.Y. Research on carbonation of fly ash geopolymeric concrete. China Rural Water Hydropower 2015, 7, 121-130.

17. Jiang, N.; Zhao, J.H.; Sun, X.Z.; Bai, L.Y.; Wang, C.X. Use of fly-ash slurry in backfill grouting in coal mines. Heliyon 2017, 3 , e00470. [CrossRef] [PubMed]

18. Cavusoglu, I.; Yilmaz, E.; Yilmaz, A.O. Sodium silicate effect on setting properties, strength behavior and microstructure of cemented coal fly ash backfill. Powder Technol. 2021, 384, 17-28. [CrossRef]

19. Liu, L.; Xin, J.; Zhang, B.; Zhang, X.Y.; Wang, M.; Qiu, H.F.; Chen, L. Basic theories and applied exploration of functional backfill in mines. J. China Coal Soc. 2018, 43, 1811-1820.

20. Zhang, X.Y.; Jia, Y.H.; Wang, M.; Liu, L. Experimental Research on Heat Transfer and Strength Analysis of Backfill with Ice Grains in Deep Mines. Sustainability 2019, 11, 2486. [CrossRef]

21. Chen, L.; Liu, L.; Zhang, X.Y.; Wang, M. Mechanism of backfill thermal utilization adsorption cooling system in deep mine. J. China Coal Soc. 2018, 43, 483-489.

22. Zhang, X.Y.; Xu, M.Y.; Liu, L.; Huan, C.; Zhao, Y.J.; Qi, C.C.; Song, K.I. Experimental study on thermal and mechanical properties of cemented paste backfill with phase change material. J. Mater. Res. Technol. 2020, 9, 2164-2175. [CrossRef]

23. Ghoreishi-Madiseh, S.A.; Hassani, F.; Abbasy, F. Numerical and experimental study of geothermal heat extraction from backfilled mine stopes. Appl. Therm. Eng. 2015, 90, 1119-1130. [CrossRef]

24. Wu, D.; Zhang, Y.L.; Wang, C. Modeling the thermal response of hydrating cemented gangue backfill with admixture of fly ash Thermochim. Acta 2016, 623, 86-94. [CrossRef]

25. Sharma, L.K.; Sirdesai, N.N.; Sharma, K.M.; Singh, T.N. Experimental study to examine the independent roles of lime and cement on the stabilization of a mountain soil: A comparative study. Appl. Clay. Sci. 2018, 152, 183-195. [CrossRef]

26. Broms, B.B. Stabilization of soft clay with lime and cement columns in southeast: Proc International Conference on Engineering Problems of Regional Soils. In Proceedings of the Engineering Problems of Regional Soils. International Conference, Beijing, China, 11-15 August 1988; pp. 41-67.

27. Wang, D.X.; Wang, H.W.; Wang, X.Q. Compressibility and strength behavior of marine soils solidified with MgO-A green and low carbon binder. Mar. Georesources Geotechnol. 2017, 35, 878-886. [CrossRef]

28. Chen, Y.H.; Gao, S.H.; Chen, L.; Chen, G.; Chen, J.R. Laboratory and field test study on the improvement of marine clay slurry by in-situ solidification. Mar. Georesources Geotechnol. 2018, 37, 695-703. [CrossRef] 
29. Chan, C.M.; Mizutani, T.; Kikuchi, Y. Reusing dredged marine clay by solidification with steel slag: A study of Compressive strength. Int. J. Civ. Struct. Eng. 2011, 2, 270-279.

30. Cheng, Q.Q.; Yao, K.; Liu, Y. Stress-dependent behavior of marine clay admixed with fly-ash-blended cement. Int. J. Pavement Res. Technol. 2018, 11, 611-616. [CrossRef]

31. Yao, K.; Chen, Q.S.; Xiao, H.W.; Liu, Y.; Lee, F.H. Small-Strain Shear Modulus of Cement-Treated Marine Clay. J. Mater. Civil. Eng. 2020, 32, 04020114. [CrossRef]

32. Hua, W.X.; Fook, H.L.; Kheng, G.C. Yielding of cement-treated marine clay. Soils Found. 2014, 54, 488-501.

33. Hua, W.X. Evaluating the stiffness of chemically stabilized marine clay. Mar. Georesources Geotechnol. 2017, 35, 698-709.

34. Cheng, Q.Q. Study on Mechanical Properties of Fly Ash Cement Treated Marine Clay. Ph.D. Thesis, China University of Mining and Technology, Xuzhou, China, 2018.

35. Cheng, Q.Q.; Hua, W.X.; Liu, Y.; Wang, W.; Jia, L. Primary yielding locus of cement-stabilized marine clay and its applications. Mar. Georesources Geotechnol. 2019, 37, 488-505. [CrossRef]

36. Khalid, U.; Liao, C.C.; Ye, G.L.; Yadav, S.K. Sustainable improvement of soft marine clay using low cement content: A multi-scale experimental investigation. Constr. Build. Mater. 2018, 191, 469-480. [CrossRef]

37. Lee, F.H.; Yeong, L.; Chew, S.H.; Yong, K.Y. Strength and Modulus of Marine Clay-Cement Mixes. J. Geotech. Geoenvironmental Eng. 2005, 131, 178-186. [CrossRef]

38. Hua, W.X. Yielding and Failure of Cement Treated Soil. Ph.D. Thesis, National University of Singapore, Singapore, 2009.

39. ISO/TS17892. Geotechnical Investigation and Testing_Laboratory Testing of Soil; Part 1, Part 2 and Part 7; International Organization for Standardization: Geneva, Switzerland, 2004.

40. He, Z.J.; Chai, S.X.; Li, M. Effect of wetting and drying cycles on the compressive strength of oil-contaminated soil treated with lime and fly ash. Q. J. Eng. Geol. Hydrogeol. 2018, 26, 438-444.

41. Nilo, C.C.; Koltermann, D.S.; Scheuermann, F.; André, B.R. Compacted clay-industrial wastes blends: Long term performance under extreme freeze-thaw and wet-dry conditions. Appl. Clay Sci. 2017, 146, 404-441.

42. Zhang, X.G.; Lin, J.; Liu, J.X.; Li, F.; Pang, Z.Z. Investigation of Hydraulic-Mechanical Properties of Paste Backfill Containing Coal Gangue-Fly Ash and Its Application in an Underground Coal Mine. Energies 2017, 10, 1309. [CrossRef] 